\title{
The Challenges of "Democratic Developmental State" in Amhara Regional State: The Case of Dessie City Administration
}

\author{
Ayalew Yimer, Aliyou Wudu \\ Civics and Ethical Studies, College of Social Science and Humanities, Wollo University, Dessie, Ethiopia
}

\section{Email address:}

aliyouwudu@gmail.com (A. Wudu)

\section{To cite this article:}

Ayalew Yimer, Aliyou Wudu. The Challenges of "Democratic Developmental State" in Amhara Regional State: The Case of Dessie City Administration. Journal of Public Policy and Administration. Vol. 4, No. 2, 2020, pp. 16- 23. doi: 10.11648/j.jppa.20200402.11

Received: August 8, 2019; Accepted: September 20, 2019; Published: May 28, 2020

\begin{abstract}
Absract: Since 1991 the current Government of the Federal Democratic Republic of Ethiopia has been following a "democratic developmental" state model both at the federal, regional and local level administrations. The main objective of this study was to the main features and extent of independence of urban local governments from the influences of the private sector and identifies the critical challenges faced in the sample Urban Local Governments in Amhara National Regional State. In this study, sequential exploratory design was employed and both quantitative and qualitative (mixed) approaches were used. Data was gathered from primary and secondary sources. In the five sample town administrations, a total of 50 respondents were selected randomly and participated to solicit data through questionnaire and key informants who were purposively selected from various local government institutions. The major findings of the study showed that the local governments are not autonomous and independent from the influence of the private sector. Local government bureaucracy is not independent from the interferences of the local authorities. The capacity, commitment, and effectiveness of local authorities are not adequate. The local government employees are not ethical and lack the capacity to implement policies. The principal values and principles of democracy such as free and fair election, representation of the society in the local councils and respects of human rights are not satisfactory. A number of challenges such as lack of good governance and rule of law are identified by respondents. Based on the findings, the study recommended that local governments should build the capacity of local authorities, institutions and public employees, respect human and democratic rights, fight corruption and forge strong public private partnership.
\end{abstract}

Keywords: Democracy, Development, Capacity, Governance, Rent-seeking

\section{Introduction}

There is ample literature on the notion of the developmental state. The term developmental state refers to" state-led economic planning" practiced in East Asian and other countries. Chalmers Johnson was the first person to conceptualize the term in the 1980s. To accelerate their economy the East Asian countries such as Taiwan, Korea, Malaysia, Hong Kong, and Thailand practices developmental state after World War Second (WWII). The East Asian developmental state sets specific development goals mobilize society to achieve industrial modernization. The 'centralized' state with the strong cooperation of the private sector from a position of preeminence helps the state to fulfill the development objectives. The East Asian countries were authoritarian and corporatist. However, these regimes were able to guide the market in order to increase investment and attract foreign investment [1].

A common factor among developmental states are, among others, a committed leadership that is embedded in the 'right' context of demands, a leadership which is strongly committed to developmental goals, and which places national development ahead of personal enrichment and/or short-term political gains" [2].

According to [3], the objectives of building a democratic developmental state are to: (1) eradicate absolute and relative poverty; (2) reduce socioeconomic inequalities between different groups, classes, sexes and regions etc.; (3) provide 
safety and security; and (4) tackle threats such as environmental degradation. Rather than abiding by the free market forces of demand and supply, African countries were advised to follow the experiences of East Asian countries and rely on active state led the development and industrial policies based on planning, formulating and implementing strategies and policies. The African states were also encouraged to create a favorable and friendly environment to attract foreign investment, with capital, management and expertise. Building a democratic developmental state requires the state to have clearly defined socioeconomic objectives that necessitate active state intervention.

According to [4] democracy has some basic principles, namely: citizen participation; equality; political tolerance; accountability; transparency; regular, free and fair elections; economic freedom; control of the abuse of power; respect of human and democratic rights; the separation of the powers of the executive, the legislature and the judiciary; accepting the result of elections; a multiparty system and the rule of law.

In Ethiopia, the term developmental state is increasingly being used in recent times. In his keynote address delivered on the $13^{\text {th }}$ of December 2010 at the $5^{\text {th }}$ International Conference on Federalism, the late Prime Minister of the Federal Democratic Republic of Ethiopia said that "Democratic federalism is one of the two pillars of our national Renaissance. Together with the establishment and consolidation of an effective developmental state in our country, it has enabled us to begin the long road back to the frontiers of our civilization [5].

Amhara national regional state is one of the nine constituent regions with a second large population (next to Oromiya regional state), with its own regional constitution, the legislative, the executive and the judiciary organs. For the past 25 years, the regional state has implemented the development plans and strategies within the local governments in the regional state.

This study has the general objective of assessing the main features and extent of independence of urban local governments from the influences of the private sector and identifies the critical challenges faced in the sample Urban Local Governments in Amhara National Regional State.

\section{Scope of the Research}

The scope of this study is limited to key issues of democratic developmental state with a particular focus on the financial capacity and political challenges of the local urban governments, the relative autonomy of the government and the bureaucracy from each other and the level of trust, cooperation and partnership of the public and private sectors in some selected urban governments in the Amhara National Regional State. This study also covers some town administrations which are the capital city of five Zonal Administrations in the eastern part of Amhara regional state.

\section{Significance and Justifications of the Research}

The findings of this research are intended to have significances for a number of stakeholders. It is believed to help the local authorities, the private sector, and the community at large to have a wider understanding and knowledge on the real challenges of "democratic developmental" states in their respective local governments.

The final results of this study will also encourage the stakeholders to learn from each other and contribute toward local economic development. Furthermore, local leaders will get the ideas on how to mobilize the communities and other scarce resources to sustain local economic development and register accelerated economic growth.

The final findings of the study may facilitate a dialogue and thereby strengthening the linkage among development actors at the local level. This will create an opportunity to the local people to have a vibrant local economy and create additional employment opportunity in the municipalities. The final outcome of this study will be essential for local government authorities in the sample areas. The study will help policy makers understand the views of their constituents and the critical challenges of democratic urban developmental states in the study areas.

\section{Methods and Materials}

This study employed both quantitative and qualitative (mixed) approach. [6] argued that that mixed approach provides strengths that offset the weaknesses of both quantitative and qualitative research. For instance, quantitative research is weak in understanding the context or setting in which people behave, something that qualitative research makes up for. On the other hand, qualitative research is seen as deficient for biased interpretations made by the researcher and the difficulty in generalizing findings to a large group. Quantitative research does not have these weaknesses.

\subsection{Description of the Study Area}

Dessie town is the capital city of South Wollo Zone. Previously, Dessie was called Lakomolza. It was founded in 1885 by king Michale. Dessie town is bordered by Kombolcha in the East, in the West by Dessie Zuria Woreda, in the North by Tehuledere Woreda, in the South by Dessie Zuria Woreda. The town is located about 2400-3200 meters from sea level. On average it is found at 2600 meters. Dessie has a highland temperature. The average annual temperature of the town is $19.82^{\circ} \mathrm{C}$. The annual monthly temperature of the town is maximum of $>27.27^{\circ} \mathrm{C}$. and minimum temperature of $<12.37^{\circ} \mathrm{C}$. The town has $1100 \mathrm{~mm}$ average annual rainfall.

It has 158.29 meter square area or 15,829 hectare including the rural Kebeles. According to the revised master plan, the area of the town is about 7200 hectares. There are 
36 public institutions, $10 \mathrm{Sub}$ cities and 6 rural Kebeles. According to the 2009 E. C. population projection, there were a total of 228,687 populations of which 189,381 were urban population ( 86,880 males and 102,502 females) and 39,306 rural population (20,207 males and 19,100 females). According to the information from Dessie town administration, in 2010 , there were 239,620 populations of which 112,121 were males and 127,499 females.

\subsection{Target Population and Sample Size}

The population refers to all individuals of interest to the researcher to whom he/she wants to generalize the result. The study populations in this research are employees of the government offices. These include (1) Trade and Industry Office, (2) Customs and Revenue offices, (3) Finance and Economic Development offices, (4) Municipality administration and (5) Urban State Councils of Dessie town administrations. In addition to these government offices, data were gathered from local democratic institutions such as media (1), Ethics and Anti-Corruption offices (1), Auditor (1), and Chamber of Commerce (1).

In research there is a general rule of thumb that could govern the sample size. For small populations $(\mathrm{N}<100)$, there is little point in sampling and surveys should be sent to the entire population. For population size $=50050 \%$ of the population should be sampled. For population size $=1,500,20 \%$ should be sampled. Finally, at approximately $\mathrm{N}=5,000$ and beyond, the population size is almost irrelevant and a sample size of 400 is adequate. Thus, the larger the population, the smaller the percentage needed to get a representative sample.

There are also other considerations in selecting a sample. One is the characteristics of the sample. Larger samples are needed for heterogeneous population; smaller samples are needed for homogeneous populations. The second consideration is cost of the study. A minimum number of participants are needed to produce valid results. A total of 50 samples were participating in the study. Participants were chosen from local government, public offices of Dessie town such as Trade, Customes and Revenue office, municipal Administration, Bureau of Finance and Economic development, and Urban Council.

\subsection{Data Collection Techniques}

A key informant face-to-face interview was conducted with the sector office heads/experts of the selected sample towns. Structured close and Open-ended interview is important to know the perceptions, views, knowledge and direct experiences of different, but still relevant bodies on the subject matter [7]. The Face-to-face interview is the most expensive method of data collection because it takes time to locate and contact respondents and travel to the respondents [8]. The qualitative data collected served to refine and fill gaps and triangulate the interpretation of quantitative data.

\section{Theoretical Perspective and Literature Review}

\subsection{Definitions of a Developmental State}

There is no consensus on the meaning of the term 'developmental state'. Some even question the appropriateness of the term 'developmental state' contending that a 'state' as an abstract entity can neither be developmental nor non-developmental, and it is perhaps a 'regime'.

A 'Developmental state', or hard state refers to the phenomenon of state-led macroeconomic planning in East Asia in the late $20^{\text {th }} \mathrm{c}$. In this model of capitalism (sometimes referred to as state development capitalism), the state has more independent, or autonomous, political power, as well as more control over the economy. A developmental state is characterized by having a strong state intervention, as well as extensive regulation and planning. The other characteristics include (i) emphasis on market share over profit; (ii) economic nationalism; (iii) protection of fledging domestic industries; (iv) focus on foreign technology transfer; (v) large government bureaucracy; (vi) alliance between the state, labor and industry called corporatism; (vii) skepticism of neo-liberalism and the Washington Consensus; (viii) prioritization of economic growth over political reform; (ix) legitimacy and performance; (x) emphasis on technical education. The term has subsequently been used to describe countries outside East Asia, which satisfy the criteria of a developmental state. Botswana, for example, has warranted the label since the early 1970s. The developmental state is sometimes contrasted with a predatory state or weak state [2].

The first person to seriously conceptualize the developmental state was Chalmers Johnson. He wrote in his book "Ministry of International Trade and Industry (MITI) and the Japanese Miracle". In states that were late to industrialize, the state itself led the industrialization drive, that is, it took on development functions. These two differing orientations toward private economic activities, the regulatory orientation and the developmental orientation, produced two different kinds of business-government relationships. The United States is a good example of a state in which the regulatory orientation predominates, whereas Japan is a good example of a state in which the developmental orientation predominates.

Recent writing on developmental states has emphasized the importance of both infrastructural powers and political commitment. According to [2], a 'developmental' state project must possess at least two essential attributes. First, the state must have the capacity to control a vast majority of its territory and possess a set of core capacities that will enable it to design and deliver policies; secondly, the project must involve some degree of reach and inclusion, and have an institutional, long-term perspective that transcends any specific political figure or leader, and emphasizes commitment. In his view, an ideal-type developmental state is one that demonstrates a 'determination and ability to 
stimulate, direct, shape and cooperate with the domestic private sector and arrange or supervise mutually acceptable deals with foreign interests'. Thus, a developmental state is broadly understood as one that evinces a clear commitment to a national development agenda, that has solid capacity and reach, and that seeks to provide growth as well as poverty reduction and the provision of public services [9].

A regulatory state governs the economy mainly through regulatory agencies that are empowered to enforce a variety of standards of behavior to protect the public against market failures of various sorts, including monopolistic pricing, predation, and other abuses of market power, and by providing collective goods (such as national defense or public education) that otherwise would be undersupplied by the market. In contrast, a developmental state intervenes more directly in the economy through a variety of means to promote the growth of new industries and to reduce the dislocations caused by shifts in investment and profits from old to new industries. In other words, developmental states can pursue industrial policies, while regulatory states generally cannot [9].

As in the case of Japan, there is little government ownership of industry, but the private sector is rightly guided and restricted by bureaucratic government elites. These bureaucratic government elites are not elected officials and are thus less subject to influence by either the corporate-class or working-class through the political process. The argument from this perspective is that a government ministry can have the freedom to plan the economy and look to long-term national interests without having their economic policies disrupted by either corporate-class or working-class shortterm or narrow interests. The following are some of the characteristics of a traditional Asian-type developmental state [10].

1. Highly competitive, extensive, relatively efficient and effective bureaucracy;

2. State-led development known as developmentalism;

3. Interventionist political elites;

4. Meticulous planned process of economic development;

5. Substantial, sustained and real increase in per capita income; and

6. Mobilize society around national development).

\subsection{An Overview of Developmental State in Ethiopia}

The government of Ethiopia has explicitly committed to building a democratic developmental state. The state efficiently guides the national socioeconomic and political development of the country by mobilizing the human and material resources of the country and directing them towards the realization of common goals. The government authorities place the needs of the poor and social issues such as health care, housing, infrastructure, education, poverty alleviation and reduction as well as a social safety net at the top of the national agenda. The official document of the government said that the country is led by a dedicated, radical and committed leadership bestowed with the vision and strategy to fundamentally transform the socioeconomic face and makeup of the nation in a relatively short period of time. Starting from a very dismal and low base of economic and human development as of 1991, considerable achievements in a large number of socioeconomic and political spheres have already been registered throughout the country. The tireless struggles to improve the living standard and overall well-being of the rural and urban populations across the country, to ensure the rule of law and to safeguard human and democratic rights are continuing [11].

However, a lot remains to be done when compared to the constitutional democracy that the country and state strived to achieve. Attracting foreign and local investors need peace and stability throughout the country. Furthermore, the current regime relentlessly should strive to root out rent-seeking, predatory behavior, corruption and other malpractices in the public bureaucracy. Building an ethical, customer-friendly, efficient and meritorious public service, a well-functioning public-private sector alliance and collaboration, creating an investor friendly environment, supporting small business development and peasant agriculture productivity as well as commercialization of small-scale agriculture, generating massive employment opportunities for the urban youth and women, encouraging export-led growth of the agricultural sector, and using state owned enterprises effectively and driving strategic investment initiatives are also critical to build a democratic developmental state. For the last six or seven years, double-digit annual economic growth has been a characteristic pattern of the national economy. The government has formulated and launched a five-year Growth and Transformation Plan (GTP) with an over-ambitious aim of doubling the present national economy or gross domestic product with an expected yearly economic growth of $11-14 \%$ at the end of the five-year period (2011-2015).

The FDRE government is also strongly committed to playing a big role in keeping the economy competitive and close to the leading edge in the global development of knowledge and technology by pursuing a democratic developmental state, akin to the current experiences of similar developmental states such as South Africa, Botswana, Mauritius, Ghana, Brazil, among others [11]. However, academics and business elites in Ethiopia equated with the mere imposition of 'hard power' and authoritarian rule on the society with the sinister aim of perpetuating one-party rule under the guise of implementing socioeconomic and political policies and programs in order to achieve faster and accelerated economic development and to extricate the poor masses from the scourges of poverty and depravation in a short period of time. This is because of the authoritarian political system that was prevalent during the developmental process of the so-called East Asian Tigers or Newly Industrialized Countries (NICs) such as Korea, Taiwan, Singapore, etc. In the 1960s and 1980s, these countries applied authoritarian politics to implement their development policies and agendas, and achieving spectacular economic growth rates and sustainable development in just three decades or so [11]. 


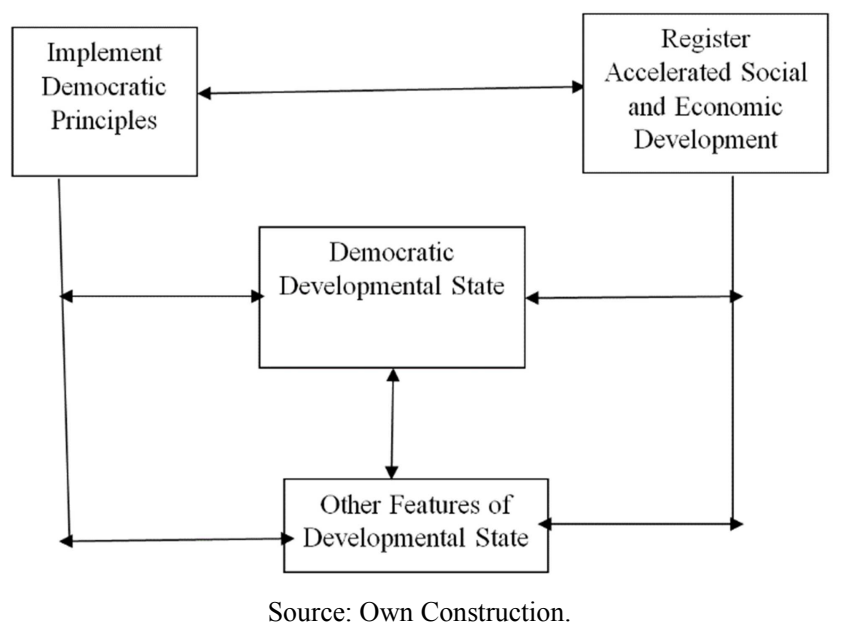

Figure 1. Conceptual Framework for Democratic Developmental State.

\section{Results}

Respondents were asked to reflect their views regarding the extent of local government independence and autonomy from the private sector. The majority of respondents indicated that local government authority's weak capacity, ineffectiveness, lack of commitment and willingness to curb rent seeking and corrupted tendencies contributed to the influence of the private sector. As could be observed from the finding of this study above, the capacity of local government authorities to plan, implement, follow-up, monitor and resource mobilization is not adequate. All these imply that the local authority's independence and autonomy are questionable.

According to respondents in the sample town administrations, the local government public employees are not working ethically and independently from the unnecessary political influence of the government. In most sample town administrations, public employees have low trust on the political system and the leaders. As to respondent there are no ethical and capable employees.

Regarding the relationship and cooperation between the private sector and the urban local governments; the majority of respondents showed that the Public-Private-Partnership is not encouraging. Furthermore, respondents said that there is a lack of conducive environment for the investors at the local levels.

In addition to lack of good governance, regionalism, and religious fundamentalism, respondents identified that absence of employment opportunities for the youth and women, inability to registerequitable growth. Lack of genuine multiparty system, lack of fair and free elections, and absence of representations of the views of the society in the local governments are the challenges identified by the respondents.

\section{Discussion}

This study has the general objective of assessing the extent of independence of urban local governments from the influences of the private sector and identifies the critical challenges faced by sample Urban Local Governments in ANRS. In order to attain this general objective, the specific objectives are to (1) analyze the extent of independence and autonomy of Urban Local Governments (ULGs) from the influence of the private sector; (2) assess the political autonomy of the bureaucracy in the selected towns; (3) explain the relationship and cooperation between the private sector and the urban local governments; (4) identify the critical challenges of democratic developmental states in the sample urban governments; and (4) assess the practices of major democratic values and principles in the sample Local Urban Governments.

The extent of independence and autonomy of Urban Local Governments (ULGS)

As mentioned in chapter two of this paper, a developmental state is characterized by the capacity to implement development plans, policies and strategies. Based on this assumption, respondents were asked to explain their views on to what extent the local authorities are effective in implementing development policies and strategies.

Table 1. Development Related Questions, Dessie Town.

\begin{tabular}{|c|c|c|c|c|c|c|}
\hline S. $\mathbf{N}$. & Items & VL & Low & Not Sure & High & VH \\
\hline 1 & Effectiveness of LG authorities & $4(8 \%)$ & $24(48 \%)$ & $11(22 \%)$ & $8(16 \%)$ & $3(6 \%)$ \\
\hline 2 & Capacity of LG authorities & $10(20 \%)$ & $15(30 \%)$ & $6(12)$ & $9(18 \%)$ & $10(20 \%)$ \\
\hline 3 & Resource mobilization capacity & $5(10 \%)$ & $5(10 \%)$ & $5(10 \%)$ & $25(50 \%)$ & $10(20 \%)$ \\
\hline 4 & Implementation capacity of LG employees & $1(2 \%)$ & $20(40 \%)$ & $9(18 \%)$ & $17(34 \%)$ & $3(6 \%)$ \\
\hline 5 & Development thinking of LG authorities & $4(8 \%)$ & $16(32 \%)$ & $16(32 \%)$ & $8(16 \%)$ & $6(12 \%)$ \\
\hline 6 & Trust of LG employees on the politics and administration & $4(8 \%)$ & $18(36 \%)$ & $10(20 \%)$ & $13(26 \%)$ & $5(10 \%)$ \\
\hline 7 & Employees trust on their leaders & $5(10 \%)$ & $18(36 \%)$ & $8(16 \%)$ & $12(24 \%)$ & $7(14 \%)$ \\
\hline
\end{tabular}

Table 1 provides different questions related to the developmental aspects of developmental states which was identified by various theories and literatures. As could be observed from Table 1 above, the local government authorities in Dessie town administration have low effectiveness to implement government socioeconomic policies and strategies. This could be due mainly to the level of education and lack of professional skill and training of local leaders. The capacity to plan, implement, follow-up and monitor development activities are a fundamental requirement for any leader. In this respect, almost 50 percent of respondents of Dessie town said that local leaders have no the necessary capacity to effect various plans and projects. Other respondents (38 percent) agree that local authorities have the capacity to plan, implement, follow-up and monitor development activities.

When asked about the capacity of local authorities to mobilize resources, majority (50 percent) of respondents said 
that local authorities usually mobilize local resources such as tax and non-tax incomes from the various private sectors who are engaged in trade and other activities. 42 percent of respondents believe that local government employees do not possess the necessary capacity to implement development plans designed at the local level. As we could be observed from the literature review section of this study, for a developmental state to be successful, there must be a well trained and skilled workforce and bureaucracy at the local level. Only 36 percent of respondents said that the local bureaucracy has the capacity to effect socioeconomic plans.

Another important feature of a developmental state as seen from the Asian Tigers is the presence of a strong developmental attitude of the leadership at all levels. The leadership must be developmentally oriented and give priority to register faster and accelerated economic growth, reduce poverty and create employment opportunities to the youth and women. In this regard, a sum of about 40 percent of respondents showed that the local leaders in Dessie town lack the quality of developmental thinking. As to key informants, there are critical problems of poverty, lack of job opportunity and infrastructure facilities in the town. A number of youth are addicted to various kinds of drugs, including "chat". About 32 percent of respondents answered the question as not sure. As the literature indicated in this paper, the presence of strong trust between and among government employees, the leadership and various actors is critical element of a developmental state. As could be observed fro Table 2 above, about 44 percent of LG employees' trust on the politics and administration is not encouraging. Employees trust on their leaders is also not strong (46 percent). This implies that in the absence of mutual trust, the development policies and strategies designed cannot be changed into reality.

Characteristics of Democratic developmental state

Table 2. Characteristics of DDS in Dessie Town.

\begin{tabular}{llll}
\hline S. N. & Items & Yes & I don't know \\
\hline 1 & Rent-seeking and malpractices & $22(44 \%)$ & $20(40 \%)$ \\
2 & Ethical and capable employees & $26(52 \%)$ & $17(34 \%)$ \\
3 & Public-Private Partnership & $18(36 \%)$ & $17(34 \%)$ \\
4 & Conducive environment for the investors & $15(30 \%)$ & $15 \%)$ \\
5 & Jobs are created for the youth and women & $17(34 \%)$ & $22(44 \%)$ \\
6 & The LG has registered a double-digit growth & $25(50 \%)$ & $13(26 \%)$ \\
\hline
\end{tabular}

A close end question was forwarded to respondents so that the main characteristics of DDS are prevalent or not in the local governments. As it has been well indicated in chapter two of this paper, democratic developmental states have common characteristics. One of the main feature of a developmental state is the fight against rent-seeking and various malpractices. Furthermore, developmental states are willing and committed in curbing and reducing corruption. In this regard, respondents were asked as to how LG authorities are fighting rent-seeking, malpractices and corrupted behaviors. About 44 percent of respondents said that LGs are fighting against corruption and other social evils while 40 percent showed that local authorities are not working to reduce rent-seeking and corruption.

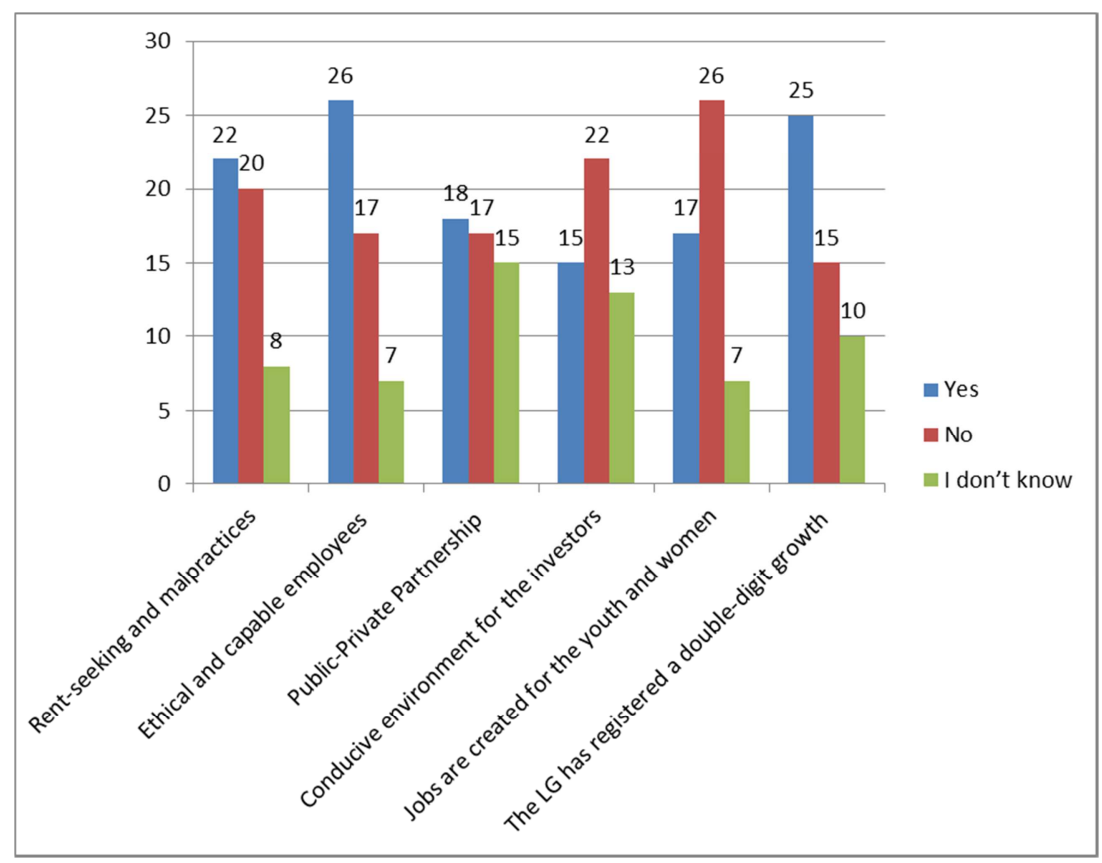

Figure 2. Characteristics of DDS in Dessie Town.

As depicted in Figure 2 above, 26 (52 percent) of respondents indicated that there are ethical, customer- 
oriented, effective, and efficient public servants at the local level. However, 34 percent of respondents answered no for this question. With regard to strong Public-PrivatePartnership (PPPs), about 36 percent and 34 percent said yes and no respectively. The rest 30 percent of respondents have no knowledge about the issue.

Developmental state is believed to create a good working environment for the private sector. In Dessie town administration, there is no favorable environment for the private sector (44 percent. And only 30 percent of respondents believe that there is a good working policy environment for the private sectors. Regarding jobs created for the youth and women at the local levels, almost half (52 percent) of respondents said that the LG authorities are nor working to create employment opportunities for the youth and women. Only 34 percent of respondents agree that local authorities are doing towards creating jobs for the youth.

The experiences of developmental sates in Asia showed that governments registered accelerated economic growth within a short period of time. The so called the "Asian Tigers" such as South Korea, Hong Kong, Thailand, Taiwan etc were able to register a fast economic growth with less than three decades. Based on this theoretical assertion, respondents were asked if LGs were able to bring doubledigit growth at the local level. About 50 percent revealed that there was a double digit economic growth in the past few years. However, 30 percent of respondents did not agree on this issue.

Challenges of democratic developmental states

Table 3. Challenges of DDS in Dessie Town.

\begin{tabular}{|c|c|c|c|c|c|c|}
\hline S. N. & Items & Strongly Disagree & Disagree & Not sure & Agree & Strongly Agree \\
\hline 1 & Lack of good governance & $8(16 \%)$ & $24(48 \%)$ & $4(8 \%)$ & $11(22 \%)$ & $3(6 \%)$ \\
\hline 2 & Regionalism & $9(18 \%)$ & $18(36 \%)$ & $9(18 \%)$ & $10(20 \%)$ & $4(8 \%)$ \\
\hline 3 & Chauvinism & $6(12 \%)$ & $17(34 \%)$ & $8(16 \%)$ & $11(22 \%)$ & $8(16 \%)$ \\
\hline 4 & Religious extremism & $11(22 \%)$ & $21(42 \%)$ & $7(14 \%)$ & $6(12 \%)$ & $5(10 \%)$ \\
\hline
\end{tabular}

As could be seen from Table 3 above, most of the respondents (48 percent) disagree and some respondents (16 percent) strongly disagree that lack of good governance is a major challenge to democratic developmental state in their town administration. However, few (22 percent) and very few (6 percent) agree and strongly disagree respectively.
About 36 percent and $12 \mathrm{n}$ percent of respondents disagree and strongly disagree respectively that regionalism is a major challenge to the developmental sate. Furthermore, respondents said that chauvinism (34 percent) and religious fundamentalism (42 percent) are not critical challenges for local governments.

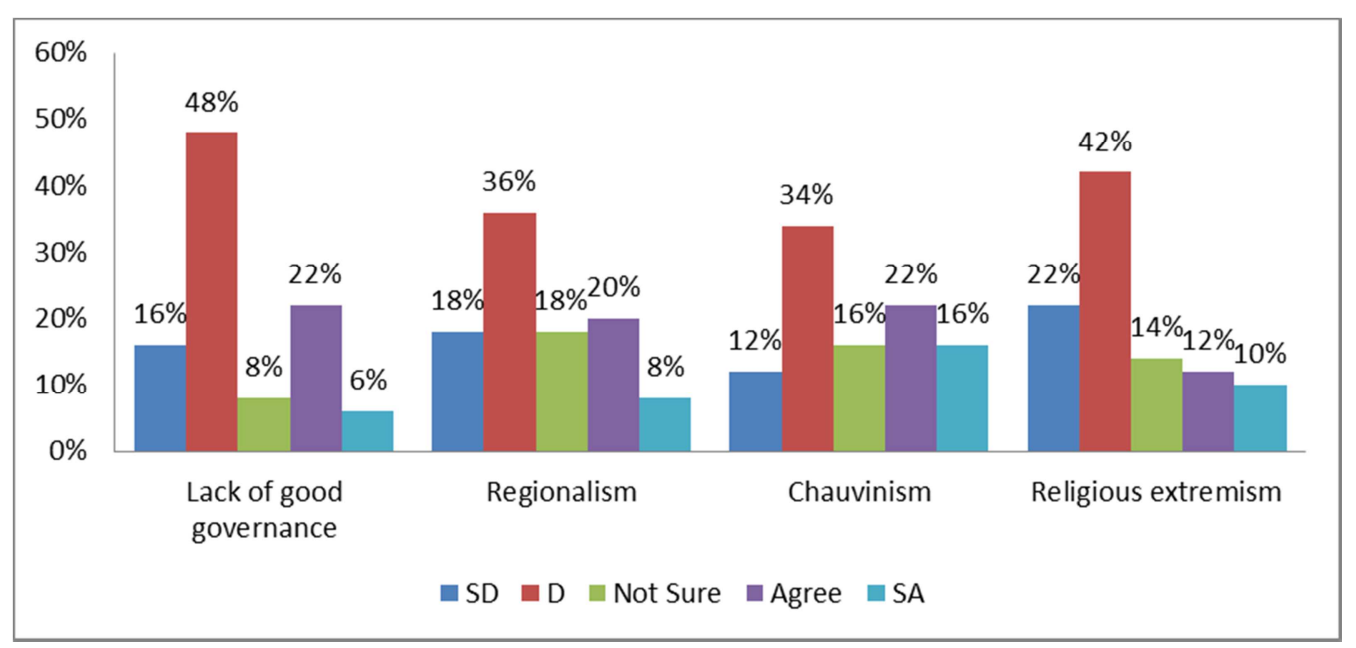

Figure 3. Challenges of DDs.

Figure 3 above showed that the majority of respondents disagree on the idea forwarded by the government of Ethiopia regarding the challenges of democratic developmental state. Key informant interview conducted with experts and office heads revealed that Low economic growth; Housing problems for government employees; absence of responsibilities of officials; lack of fighting rentseeking behavior and corruption; low attention to satisfy the public interest; local officials give priority to their own needs; high level of unemployment; high price of basic goods and services; low level of salary of public employees; favoring relatives or nepotism by local officials; lack of rule of law; low level of awareness of the society; lack of leadership commitment; and lack of honest and sincere of experts are major challenges of the government.

\section{Conclusion}

From the above discussions, it is possible to conclude that the effectiveness of local authorities and the capacity of the local government in the study area is weak. The local government is highly effective in mobilization activities 
mostly through coercion. On the other hand, employees have low implementation capacity of policies and strategies. The employees have low trust on the political leaders in the study area. Local government authorities have low development mentality.

The findings also show that regionalism and religious extremism are the most important challenges of the developmental state in the study area. Regarding the features of DDS in the study area, rent-seeking and malpractices, absence of ethical and capable employees, weak publicprivate-partnership, lack of conducive environment and low job opportunity are identified.

\section{Recommendation of the Study}

Based on the findings, the study recommended that:

1. Local governments should build the capacity of local authorities, institutions and public employees,

2. Respect human and democratic rights, fight corruption and,

3. Forge strong public private partnership,

4. Improve good governance such as the justice system, transparency, accountability, rule of law, honesty,

5. The quality of political party members should be given priority,

6. Local government authorities should work to get public trust, confidence and legitimacy to govern,

7. Give priority to the public interest,

8. Fight rent-seeking, nepotism, discrimination, groupism and corruption,

9. Improve leadership commitment,

10.Improve the problem of housing, electricity, employment,

11. Refrain from unnecessary interference.

\section{Conflict of Interests}

The authors has not declared any conflict of interests.

\section{References}

[1] Gumede, W. (2009). Delivering the democratic developmental state in South Africa. Development Planning Division. Working Paper Series No. 9, Development Bank of SouthernAfrica Limited: Midrand.

[2] Ghani, A., C. Lockhart and M. Callaghan (2005). Closing the Sovereignty Gap: How to Turn Failed States into Capable Ones, ODI Opinion 44, London: ODI.

[3] Ocloo, W. A. K. (2013). Prospects and Challenges of Constructing a Democratic Developmental State in Ghana. Culture and Works, Accra, Ghana.

[4] Edigheji, O. (2005). A Democratic Developmental State in Africa? A concept paper. Research Report 105. Center for Policy Studies, Johannesburg.

[5] United Nations Development Programme.(2010). The Challenges of 21 st century Development: Building CapabilityEnhancing States. Global Event Working Paper. New York, USA.

[6] Creswell J. W. (2007). Qualitative, Quantitative and Mixed Methods Approaches. New Delhi: SAGE Publications Inc.

[7] Quinn, P. Michael. (2002) (Third Edition). Qualitative Research and Evaluation Methods. SAGE Publications, Inc. New Delhi.

[8] Pierce, R. (2008). Research Methods in Politics: A Practical Guide. SAGE Publications Ltd; New Delhi.

[9] Fritz, V. and Rocha M. (2006). (Re) building Developmental State: From Theory to Practice. Working Paper 274. Overseas Development Institute; London; UK.

[10] Maphunye, K. (2009). Public Administration for A Democratic Developmental State in Africa: Prospects and Possibilities. Research Report 114. Ford Foundation; Johannesburg.

[11] FDRE. (2014). Challenges of Democratic Developmental State in Ethiopia. Unpublished material. 